Historic, Archive Document

Do not assume content reflects current scientific knowledge, policies, or practices. 



\section{Family Orchards}

Nothing is more healthful and palatable than good fresh fruit. Therefore, every ranch, whether it be a grain or fruit ranch, should have about one acre of ground set aside in a convenient place to be used for the growing of fruits and berries for home use.

Everyone enjoys good fresh fruit, but too often this valuable addition to the ranch home is overlooked. We no doubt have all heard the old saying, "An apple a day keeps the doctor away." This same thing we believe is true of other fresh fruits.

In order to have some variety of fresh fruit at all seasons. planters should order varieties that ripen in summer, autumn, and winter. The most popular among these fruits for home use are Apples, Apricots, Cherries, Peaches, Pears, Plums, and Quinces. Varieties of fruits can be selected which ripen at different intervals and which will enable the planter to enjoy fresh fruit continuously throughout the whole season, picked from his own family orchard. $\therefore$

\section{Information for Purchasers}

USE THE ORDER SHEET, which you will find in the back of this price catalog.

PRICES: All prices quoted in this list are for stock at Fresno.

QUANTITY RATES: Stocks mentioned in this list will be furnished as follows: 5 of a variety at the 10 rate; 0 at the 100 rate; 300 at the 1000 rate.

ERRORS: Errors or complaints must be reported within ten days of receipt of goods.

\section{Terms and Remittances}

All of our stock is sold for cash, unless other arrangements are made. Remittances can be made to us either by postoffice or express money order, registered letter, bank draft, or check. It often happens that our customers find it more convenient to send us a personal check on their local hank and such checks will be accepted for collection.

On all orders placed in advance we ask that 20 per cent deposit be forwarded with the order and we will then reserve the stocl: for shipment at any time designated by the cusromer.

\section{DESCRIPTIVE CATALOG}

(Without prices) will be mailed to you free upon request. 


\title{
Our Nursery
}

-has been serving the public in the way of furnishing Nursery stock for the planting of orchards, vineyards and ornamental gardens in California and adjoining States since the year 1885.

It gives us great pleasure to be able to point with pride to some of the very best orchards in the State, which have been grown with Fresno Nursery Company trees. We are always ready and willing to help our customers solve their planting or pruning problems, or give them the best advice we can as to the most suitable and profitable varieties to plant for their section and conditions. Being fruit growers ourselves, as well as growers of Nursery stock, we feel that we are in a position to render valuable information along this particular line.

You are cordially invited to visit and inspect our Nurseries at any time and see the care exercised by us in the growing, digging, handling, and shipping of your stock.

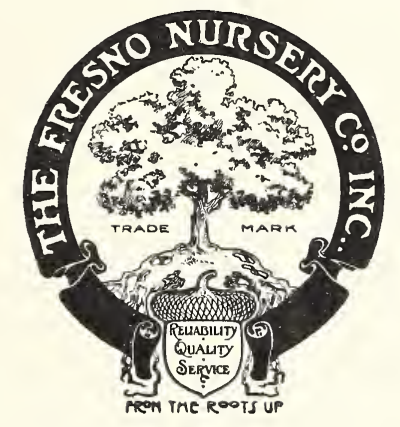

1927

\section{The Fresno Nursery Company, Inc.}

\author{
Fresno, California, U. S. A.
}



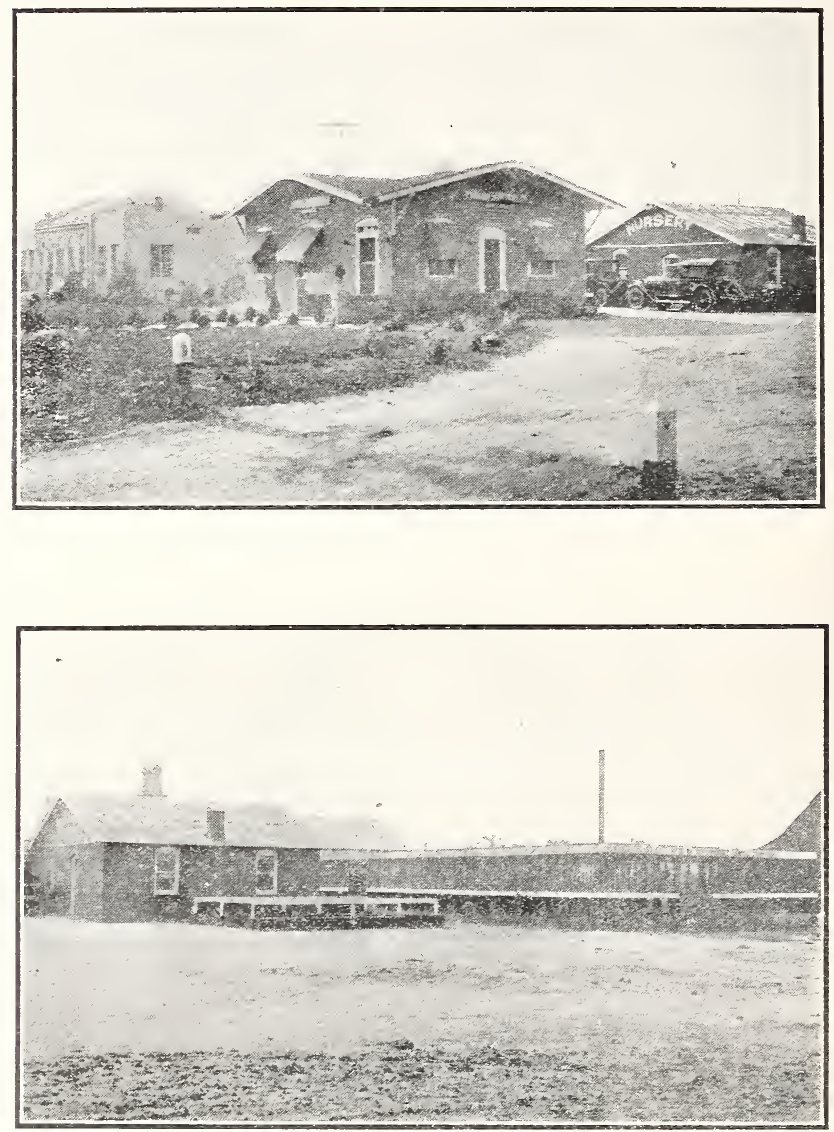

\section{NEW LOCATION}

The above illustrations represent our main office building, which we erected in 1924; also our yard office and lath house. These are located immediately south of Fresno on the State Highway on our own property.

Since the year 1885, our main office has been located in the heart of the business section in the city of Fresno, but owing to the growth of the city, parking restrictions, and the growth of our business, we found it necessary to erect our main office at our packing and heeling-in grounds immediately south of Fresno, where we have ten acres of soil particularly adapted to the heeling-in of Nursery stock. On this ten acres are also located our packing sheds, dipping plants, fumigating plants, and our own water supply.

Being located at our packing and shipping plant, we are able to personally supervise the handling of all orders. 


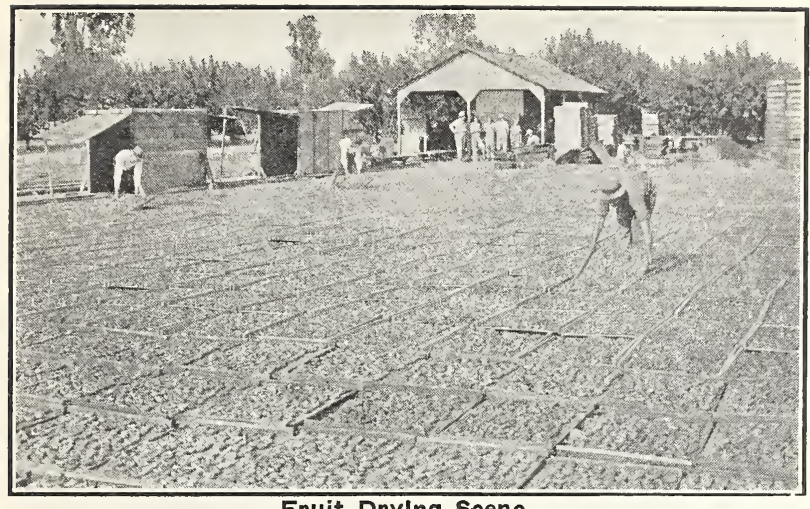

Fruit DryIng Scene

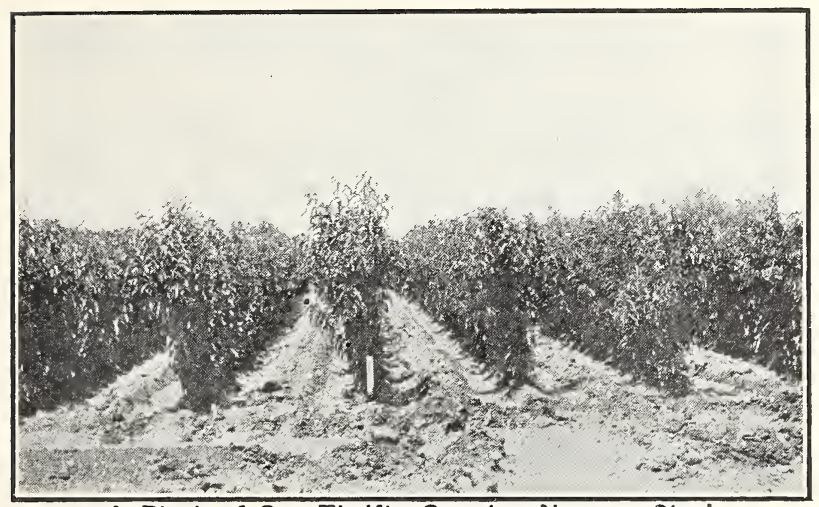

A Block of Our Thrifty Growing Nursery Stock

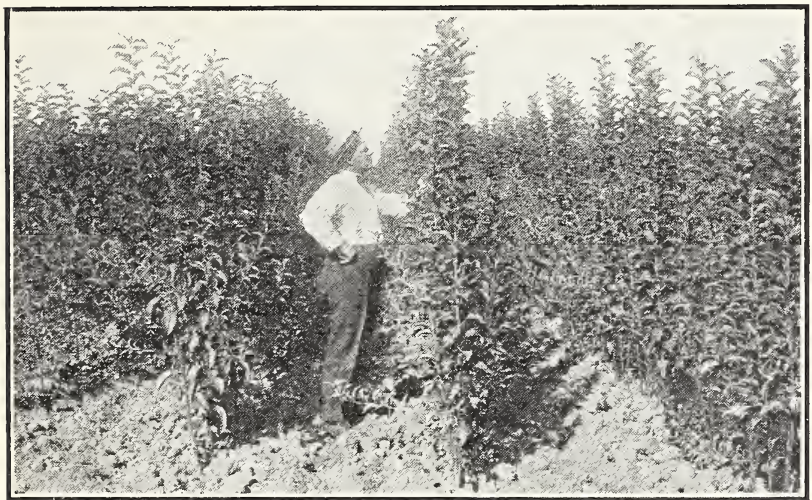

Another Scene in Our Nursery

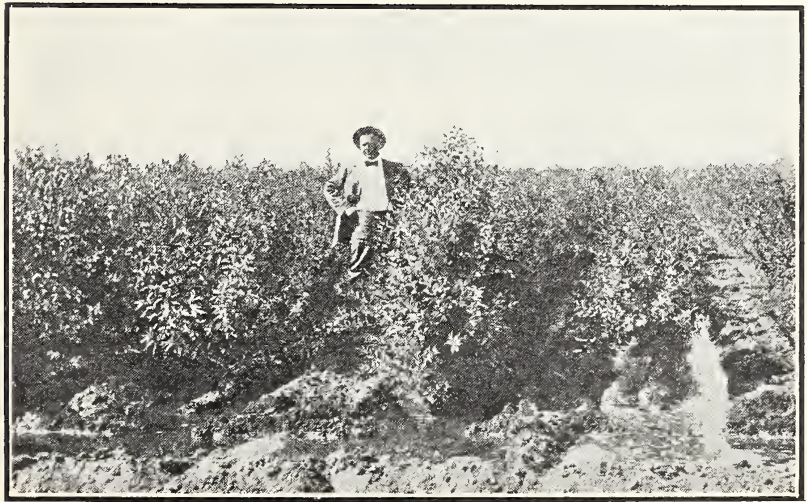

Seedlings Ready for Budding 


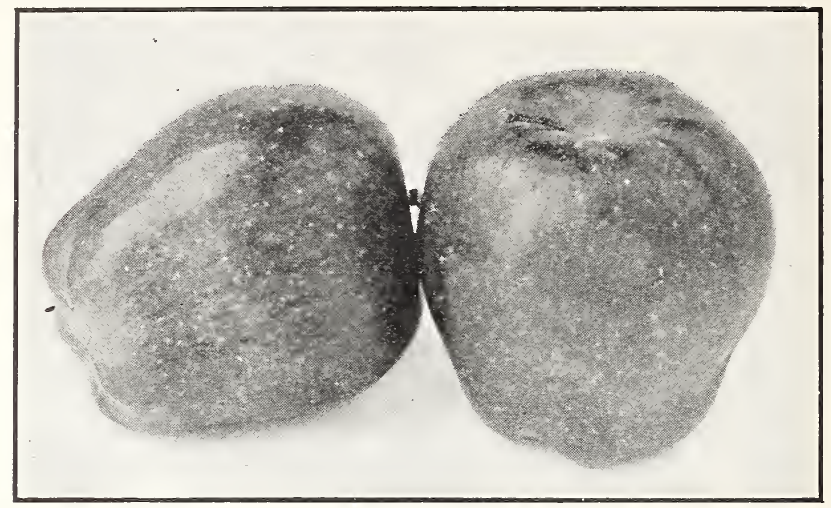

\section{APPLES}

The Apple is undoubtedly the best known and most widely grown fruit in the world. This is chiefly due to its popularity and its adaptability to sections where frost is often so heavy that other fruits can scarcely exist.

The varieties we have listed are the best summer and winter Apples for planting throughout the different sections.

\begin{tabular}{|c|c|c|c|c|c|}
\hline & & $\begin{array}{l}\text { ach } \\
\text { ate }\end{array}$ & $\begin{array}{r}10 \\
\text { Rate }\end{array}$ & $\begin{array}{r}100 \\
\text { Rate }\end{array}$ & 1000 \\
\hline 6 to $8 \mathrm{ft} .\left(3 / 4^{\prime \prime}\right.$ & up).... & .75 & $\$ .60$ & $\$ .50$ & $\$ .45$ \\
\hline 4 to $6 \mathrm{ft} .\left(1 / 2^{\prime \prime}\right.$ & up) & .70 & .55 & .45 & .40 \\
\hline 3 to $4 \mathrm{ft} .(3 / 8)$ & up) & .65 & .5 & .40 & .35 \\
\hline to $3 \mathrm{ft} .\left(1 / 4^{\prime \prime}\right.$ & up) & .55 & .40 & .30 & .25 \\
\hline
\end{tabular}

Arkansas Black Medium to large, with a smooth waxy skin of a most beautiful dark red color, turning almost black on the sides exposed to the sun. The flesh is decidediy yellow tinged, fine, firm and crisp. Ripens in December and keeps well until Aprii.

Delicious The fruit of this variety is all that its name implies. It is large and uniform in size and its shape is long and tapering, being uniquely ribbed and having distinct knobs at the blossom end of the fruit. The skin is thin and tough, yellow in color, marked with dark red, with a crimson cheek on the sunny side. The flesh is white, fine grained, crisp, juicy, melting, sweet, slightly acid, and has a very fragrant aroma. Ripens in November.

Early Harvest Medium size and quite roundish; the skin is very smooth, of a bright straw color with a few faint dots of white. The flesh is white, juicy and crisp with a rich subacid flavor, which makes it very valuable among early apples for its high cooking qualities. Late July. Esopus Spitzenburg Large; tapering; light red, delicately coatcrisp, rich, sprightly, vinous flavor; one of the best. November.

Gravenstein Large; striped red and orange. Most popular early variety on Coast. August.

Jonathan Medium to large; conical; striped, mostly red; tender, juicy, rich vinous flavor; very productive; good keeper; one of the best varieties for table or market. October.

Red Astrachan One of the oldest Russian type apples in the United States. The fruit is of medium size, roundish and flat, sides somewhat unequal. The skin is rather thin, quite tender, smooth, of a yellow or greenish tinge, usually striped with deep crimson or carmine, and dotted with numerous whitish dots. The flesh is of a whitish tinge, sometimes bearing a small trace of red, rather fine, tender, crisp and juicy with a brisk sub-acid flavor. Ripens in July.

Red June Roundish and uniform, having a tender, smooth, glossy skin, of pale yellow or greenish overspread with a deep red, sometimes very dark on the exposed cheek. Some specimens are entirely red with rather numerous dots, which are very small and light. The flesh is white, tender, juicy and of a rich sub-acid flavor. Used principally as a dessert fruit. Ripens in July.

Rome Beauty Large; yellow striped with bright red; very keeper. October. handsome; flesh tender, juicy, sprightly. A long 
White Astrachan Large size, roundish and flat at both ends and is very attractive. The skin is a deep waxen yellow color, showing faint streaks of red or pink. Flesh is white and quite acid, making it highly prized for culinary purposes. Ripens in early July.

White Winter Pearmain This variety is considered among the leading fruit growers as being one of the most profitable winter apples grown on the Pacific slope. The fruit is medium to large in size, very uniform and of a roundish oblong shape. The skin is smooth, greenish at first, then gradually turning to a pale waxen yellow flushed on the sunny side with a brownish red and covered with numerous pale or russet dots. The flesh is of a yellow tinge, firm and fine grained, tender, crisp, juicy, with a pleasing aroma. Ripens the latter part of November.

Winesap Medium size; oblong; skin smooth, dark red; flesh yellow, firm, crisp, with a rich, high flavor; a productive bearer. November.

Winter Banana Large size and in shape is roundish to conical and sometimes very flat at the base. The skin is smooth, tough, moderately thick, waxy and of a yellow color, which when ripe often has a blush of dark pinkish red, sometimes covered with whitish or fine russet dots. The flesh is of a whitish color, tinged with a pale yellow, crisp, tender, mild sub-acid, and a little coarse.

It is a very delicious apple for table use on account of its banana-like flavor. Ripens in October.

Yellow Bellflower Rather large and oblong and more or less ribbed, often with prominent ridges at the apex, sides being sometimes unequal. The skin is of a decidedly attractive color, being shaded and often blushed with a brownish red in the sun, which improves greatly by becoming a more clearly defined yellow as it matures in storage. The flesh is whitish, tinged with a pale yellow and moderately fine grained, rather tender, juicy and possesses a fine aroma. Ripens in October.

Yellow Newtown Pippin While uniform in size, varies greatly in form, which is usually roundish, oblate and somewhat angular. The skin is rather tough, slightly roughened with brownish russet dots and inclined to be of a greenish shade at harvesting time, but afterwards attains a very pretty yellow showing a slight trace of brownish pink near the base. The flesh is of a yellow tinge, firm, tender, fine grained and sub-acid. May.

Ripens in December and keeps well until the latter part of

\section{CRAB APPLES}

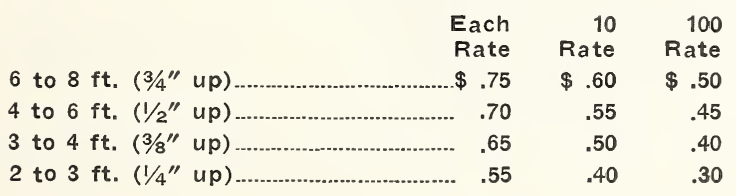
Red Siberian The fruit is about three-fourths to an inch in base. The skin is of a lively scarlet color and very smooth, having a yellow ground and usually covered with a white bloom. When the bloom is rubbed off, it presents a very highly polished appearance, which makes it particularly prized for fruit basket decoration. Ripens in September.

Transcendent The tree is a vigorous upright grower and comes into bearing at an early age. The fruit is rather large, flattened at the end, of a golden yellow color, with a rich red cheek, and covered with a delicate pale blue bloom when ripe. Ripens in September.

Yellow Siberian The fruit is of a large size, beautiful golden yellow, or amber, in color and is borne in clusters. The flesh is a beautiful amber color, juicy, sub-acid and highly prized for the making of preserves and jellies.

On account of the high quality and the attractive appearance of this variety, we believe every family orchard should contain one or more of these trees. Ripens in September. 


\section{APRICOTS}

The Apricot is one of the earliest and best fruits for eating fresh, canning or drying.

It is also one of the most profitable fruits to plant owing to the fact that there are very few produced outside of California.

\begin{tabular}{|c|c|c|c|c|}
\hline & $\begin{array}{l}\text { Each } \\
\text { Rate }\end{array}$ & $\begin{array}{r}10 \\
\text { Rate }\end{array}$ & $\begin{array}{r}100 \\
\text { Rate }\end{array}$ & $\begin{array}{r}1000 \\
\text { Rate }\end{array}$ \\
\hline $\begin{array}{l}\text { to } 6 \mathrm{ft} .\left(1 / 2^{\prime \prime} \text { up }\right) \\
\text { to } 4 \mathrm{ft} .\left(3 / 8^{\prime \prime} \text { up }\right) \\
\text { to } 3 \mathrm{ft} .\left(1 / 4^{\prime \prime} \text { up }\right)\end{array}$ & $\begin{array}{l}.70 \\
. \quad .65 \\
.55\end{array}$ & $\begin{array}{r}\$ .55 \\
.50 \\
.40\end{array}$ & $\begin{array}{l}\$ .45 \\
.40 \\
.30\end{array}$ & $\begin{array}{l}\$ .40 \\
.35 \\
.25\end{array}$ \\
\hline
\end{tabular}

Blenheim The fruit is above medium in size, oval in shape, and of a deep orange color. The flesh is a beautiful yellow color, juicy and possesses a very fine flavor. We do not hesitate in recommending this variety to planters in all apricot sections, as it has proven to be a money maker wherever planted. Ripens early part of June.

Derby Royal Practically the same as the old Royal with the exception of ripening a trifle earlier, which, of course, makes it very desirable for early shipping purposes.

Growers of Derby Royals have received from $\$ 150.00$ to $\$ 200.00$ per ton this past season for their fruit.

Hemskirke On account of its large size and fine quality, it is highly appreciated in the local markets and by home orchardists in general. Ripens the latter part of June.

Large Early Montgamet The fruit is large, rather flat in shape, and deep golden in color. Flesh is orange colored, rich and juicy. Ripens early June.

Newcastle Early Originated at Newcastle, California, and is valued for market purposes on account of its early ripening period. The fruit is medium size, freestone, rich in flavor and highly colored.

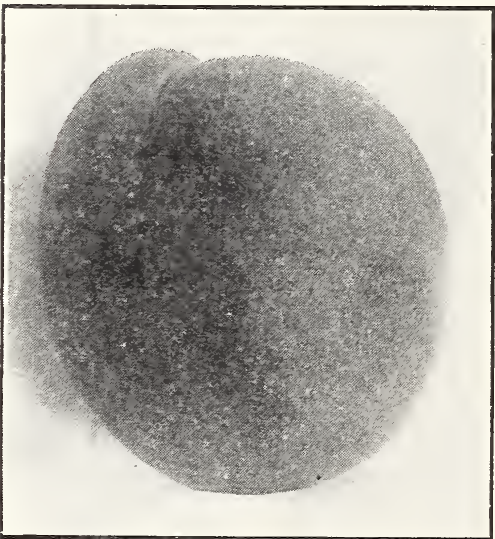

Royal

Routier's Peach Large, yellow in shade; deep orange mottled or splashed with red in the sun; flesh juicy and rich, with high flavor. July.

Royal Large, roundish, compressed. The skin is a deep yellow flushed with red on the sunny side. The flesh is of a light yellow color, juicy, firm and has a most delicious flavor. Early June.

Tilton Large size, somewhat flat in shape is a light orange yellow, and orange color. The flesh firm, and has a delightful apricot flavor, and ripens very uniformly on the tree. Excellent for canning, but also valuable for shipping and drying. Ripens middle of June.

\section{CHERRIES}

The earliest fruit grown, and while enormous returns are received from the commercial shipping of this variety, it is also very desirable for canning and home uses.

\begin{tabular}{|c|c|c|c|c|c|}
\hline & & $\begin{array}{l}\text { Each } \\
\text { Rate }\end{array}$ & $\begin{array}{r}10 \\
\text { Rate }\end{array}$ & $\begin{array}{r}100 \\
\text { Rate }\end{array}$ & $\begin{array}{r}1000 \\
\text { Rate }\end{array}$ \\
\hline $\begin{array}{l}6 \text { to } 8 \mathrm{ft} .\left(3 / 4^{\prime \prime}\right. \\
4 \text { to } 6 \mathrm{ft} .(1 / 2), \\
3 \text { to } 44 \mathrm{ft} .\left(3 / 8^{\prime \prime}\right. \\
2 \text { to } 3 \mathrm{ft} .\left(1 / 4^{\prime \prime}\right.\end{array}$ & 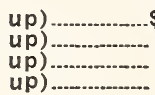 & $\begin{array}{l}.65 \\
.60 \\
.55 \\
.50\end{array}$ & $\begin{array}{l}\$ .50 \\
.45 \\
.40 \\
.35\end{array}$ & $\begin{array}{l}\$ .40 \\
.35 \\
.30 \\
.25\end{array}$ & $\begin{array}{l}\$ .35 \\
.30 \\
.25 \\
.20\end{array}$ \\
\hline
\end{tabular}


Bing The fruit is very large, heart shaped, and when fully ripe the skin is almost black. The flesh is firm, meaty, sweet and delicious and is of a purplish red color. Considered one of the best of the black sweet cherries. Ripens middle of June.

Black Tartarian This is a great favorite on account of its is large, heart shaped, and the skin is black and glossy. The fruit is reddish purple in color, tender, with a small stone, and is of unsurpassed quality. Ripens the middle of June.

Burbank Originated by Luther Burbank and is the largest and purplish black in color and very beautiful in appearance. Ripens in early May.

Early Richmond Is very productive and a good market is used for canning 'purposes of the sour cherry type. The fruit The skin begins to color red at an early stage and becomes a beautiful dark red when fully ripe, at which period the fruit has a very delicious sprightly acid flavor and is very juicy.

Lambert This is the largest red cherry yet produced. The a beautiful tree is very hardy and a vigorous grower and forms a beautiful head. The fruit is heart shaped, very large in size and a beautiful dark red in color. The flesh is dark red in color and a mild sub-acid in flavor. Ripens about the 10th of July. Lewelling The Lewelling is commonly known as Black RepubBlack Tartarian, being large in size and having a glossy black skin. The flesh is like that of the Napoleon Bigarreau in texture, being very firm, juicy and sweet. It is of a purplish red color, and is a very good shipper. Ripens in July.

Royal Ann (Napoleon Bigarreau) The fruit is pale yellow to a $\mathrm{m}$ b e $r$ color, overspread with a bright red. Is rather long and heart shaped. Flesh yellow, juicy and possesses a mild sweet flavor. The most extensively planted variety of all the sweet cherries. On account of its color and texture it is the favorite commercial canning and preserving variety from which the famous "Maraschino" cherry is manufactured. It is also considered the best variety for shipping to the Eastern markets. Ripens late June.

\section{FIGS}

A fine fruit for either canning, drying or preserving.

On account of climatic conditions, California is practically the only State in the Union where figs can be grown successfully.

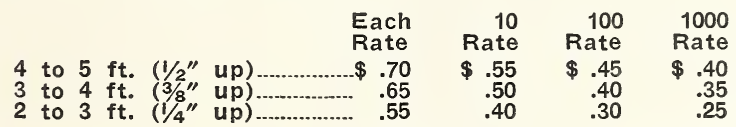

Calimyrna Fruit large to very large, skin fine lemon yellow color, flesh thick and meaty and of a dark amber color when ripe. The dried product contains a higher percentage of
sugar than any other fig. Dries readily and makes the finest comsugar than any other fig.

Planters of Calimyrnas should also plant Capri trees.

Kadota The Kadota is a vigorous grower and bears abundant crops of medium size white figs, which are used chiefly for canning and for pickling and is also recommended for its good qualities as a preserving variety. It has a very thin skin of golden yellow color. Pulp is white tinged with pink towards the center. Ripens the first week in August, slightly in advance of the White Adriatic.

Mission Commonly known as Black Mission or California Black and is one of the oldest figs grown in California. The fruit is large, having a rough but thin skin, of a deep violet color; quite sweet, but not of a strong flavor.

The one great advantage of this fig, as a market product over other figs, is the fact that it seldom sours. Where one is desirous of growing figs for shipping and for supplying local markets, this variety is highly recommended. 
White Adriatic Is probably more widely known and more extensively grown than any other fig. The fruit is of medium size, roundish, with a medium neck. Skin is very thin, greenish in shade, turning to yellow when ripe. The pulp is of a white color with violet streaks. Ripens middle of August.

\section{WILD OR CAPRI CLASS}

We have already mentioned the necessity of planting the Capri or Wild Figs with the Calimyrnas for fertilization purposes. Don't fail to include Capri trees with order of Calimyrnas.

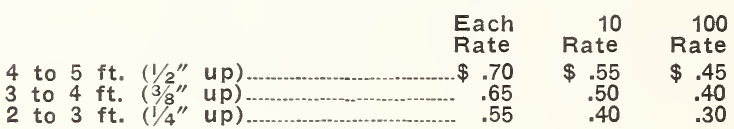

Capri No. 3 The earliest of the Capri figs, maturing its fruits about the first of June. The tree is a spreading grower, the branches heavy and closely jointed; considered to be the best of all.

Capri Stanford This fig is large, and ripens immediately after the Capri No. 3. A heavy producer.

\section{NECTARINES}

A delicious, smooth-skinned fruit which thrives best in the interior valleys of the State. In habit of growth and general appearance the tree is hard to distinguish from the peach. The fruit is of exceptionally fine flavor and when dried or canned is highly prized by fruit lovers.

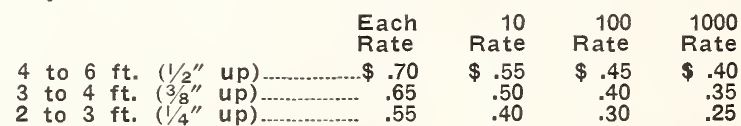

Gower Fruit medium size and round; skin yellowish-green overspread with deep red; flesh creamy white, reddish pink at the pit. Fine for early market. Ripens early July.

New White Is commercially considered the best white nectarine on the market. The fruit is large and almost round, having a fine white skin with often a tinge of red on the exposed side, which makes it very attractive. The flesh is white, juicy, of high quality, and separates freely from the pit. Ripens in July.

Stanwick The Stanwick originated in England and is the recognized leader among nectarines, being of large size and particularly valuable for shipping, drying and canning purposes. The fruit is exceptionally large in size, with a pale greenish skin shaded deep rich violet. The flesh is white, very tender, juicy and separates freely from the pit.

The Stanwick is highly recommended to the planter as one of the most profitable nectarines grown, always yielding enormous crops, which demand the highest prices. Ripens in August.

Victoria The fruit is exceptionally large, round in form and somewhat flat at the top. The skin is of a yellow color on a greenish ground, blushed with deep rich red on the side exposed to the sun. Flesh is very sweet, rich and delicious.

Although of recent introduction to growers of this State, it has steadily increased in popularity as a valuable drying and shipping variety. Ripens the middle of August. 

Foster The Iruit is large and uniform in size, slightly flattened.
The skin is a deep orange in color, with a dark red cheek in the sun. Flesh is bright yellow in color, rich and juicy. It is highly recommended for its table uses and for its fine shipping and drying qualities. Ripens about the same time as the Early Crawford.

Hale's Early This peach is a large early freestone and originated in the State of Ohio. The skin is of a greenish color mottled with red when ripe; the flesh is white, melting and rich.

Hale's Early is a fine variety for house use and is considered a good variety for local markets. One particularly good feature about this peach is the fact that it is very easily peeled. Ripens early in July.

J. H. Hale Originated by J. H. Hale, of Georgia, and is heralded throughout that section as one of the greatest peaches ever discovered.

The tree is a very strong and vigorous grower, having much the appearance of the Elberta. The fruit is a deep golden yellow color, overspread with bright red; has a smooth, thick skin and compares very favorably with the Elberta in shape. The flesh is firm, fine grained, and deep yellow in color. Ripens last of July.

Hauss Cling Is highly recommended in some sections of CaliforHauss Cling nia by the canners and is what is termed a midsummer cling, as it ripens just after the Tuscan. The fruit is of good size, round in shape, and clear yellow to the pit, which is very small. Ripens August 1st to 10th.

Heath Cling As a clingstone variety the Heath Cling is unequaled by any other variety of its color or season.

The fruit is very large. Skin is creamy white in color, having a faint tinge of red on the surny side. The flesh is of a greenish white color, very tender, possessing a rich flavor and a pleasing aroma, which is unequaled by any other of the late canning varieties. Besides its high value as a canning variety, it is exceptionally fine for pickling and for the nlaking of preserves. Ripens the middle of September.

Late Crawford The fruit is large, roundish, having a yellow skin and a dark red cheek. The flesh is deep yellow in color, inclined to be reddish at the pit. Ripens early in August.

Levy Late Cling The fruit is large in size and roundish in shape. The skin is a deep yellow, bearing a rich brownish shade on the sunny side. The flesh is a rich deep yellow, firm and juicy, ripening the middle of September.

Lovell Originated in California as a chance seedling and is one of the most widely planted and highly favored of any freestone variety in California today.

The tree is a vigorous grower and a heavy bearer. The fruit is very uniform in size, almost perfectly round; yellow in color. The flesh is fine, firm, yellow to the pit and contains a large percentage of sugar.

The Lovell is the best canning, drying and shipping freestone peach grown.

We do not hesitate to state that we consider this variety one of the very best peaches to plant. Its time of ripening is the last part of August.

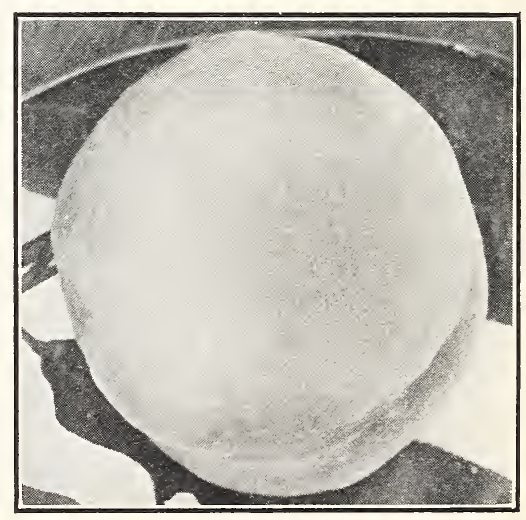

Heath Cling

Mayflower This is one of the earliest freestone varieties and sert purposes.

is highly regarded by all lovers of peaches for des-

The tree is a strong grower, late bloomer and consequently favored by those growing peaches for early market purposes. The fruit is of a light green color nearly covered with red. Flesh is creamy white, fine grained, and delicious. Ripens early in May.

McKevitt Cling The fruit is of a beautiful white color, with a faint blush of red; has a very firm, fine-grained flesh, sugary, rich and possessing an extremely high flavor. Ripens the last of August. 
Muir The Muir is the King or Queen, as it might be called, of all the freestone peaches for drying purposes in California. It is very large in size and a perfect freestone, having a clear yellow flesh, which certainly presents a most beautiful appearance when properly dried.

In addition to its attractive appearance, it contains more sugar qualities than any other peach, which allows it to dry exceedingly heavy, making it a very profitable variety to the producer. We feel that this peach is so widely known and favored among California planters that it is needless for us to mention all of its good qualities. Time of ripening latter part of July.

Palora or Peak Cling A popular midsummer variety, which is similar to the Phillips Cling, but ripens much earlier, making it a very desirable variety for commercial canning. Tree is a strong grower and heavy producer.

Phillips Cling Even size, practically the same color all through; Phillips Cling has a very small pit, is exceedingly rich in flavor and highly colored.

Flesh is very fine grained and of a lemon yellow color. The tree is a very vigorous grower and a heavy producer and for this reason is a great favorite among orchardists. Ripens early in September.

Salway The late ripening of this peach makes it a great favorite in California, for dessert purposes, coming at a time when practically all other freestones are gone.

The skin is of a yellow color, having a brown or red cheek. The flesh is yellow and inclined to be red at the pit. While it is not very juicy, it possesses a very pleasing flavor. Ripens middle of September. Sellers Orange Cling The fruit is large, uniform in size and a deep golden, very firm and of good flavor. It is highly favored by many growers in the different cling-growing districts of California because of its productiveness. It is also highly valued by canners for its fine color and uniformity of size and on account of its favorably ripening period.

Canners recommend Sellers Orange as one of the best midsummer varieties. Ripens early in August.

Strawberry Cling This is a large, beautifully colored cling, flesh is white, and inclined to be of a slight red around the pit.

It is a good shipper and on account of its attractive appearance, seldom, if ever, fails to bring good prices on the market. Ripens middle of September. Strawberry Free To those desiring a good early white peach skin is of a creamy white color, partly covered with a dark red. Flesh is very white, with a tendency to be quite red near the pit; juicy and possesses a rich flavor. We recommend the planting of this variety in all home orchards. Ripens early July. Tuscan Cling The fruit is very large and yellow in color, preof Tuscan Cling orchards that under good care and cultivation have produced from twelve to fifteen tons of fruit per acre.

To anyone familiar with the growing of cling peaches in California, we believe the Tuscan needs no further recommendation. Ripens about the middle of July.

\section{PEARS}

In favored sections of California the pear is one of the most profitable fruits for canning and shipping and, inasmuch as there are only certain sections where they can be grown successfully, no doubt the demand will exceed the supply for several years to come.

\section{Pears-On Jap, French and Quince}

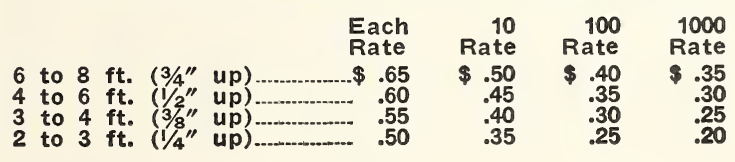


Bartlett There has undoubtedly been more money made through variety.

The fruit is of large size, skin bright yellow when ripe, inclined to blush on the sunny side, and is of oblong shape, tapering toward the stem. The flesh is exceedingly fine grained, white and buttery, full of juice and very highly perfumed. It is especially adapted to river bottom soils, but if properly cultivated will thrive in clay loams and even adobe. Ripens in August.

Beurre d'Anjou The tree of this variety is a good grower and a heavy cropper. The fruit is large, obtuse, pyriform in shape, having a short, thick stem and small calyx.

Skin is a greenish color, partially covered with russet and often shaded with a dull crimson. The flesh is white in color, melting, juicy, of vinous flavor and highly perfumed.

Does well in all sections of California. Ripens in September.

Beurre Hardy Large fruit of a greenish color covered with light russet, which is shaded with brownish red and sprinkled with brown dots. The flesh is buttery, melting, juicy and highly perfumed. This variety can be grown very successfully on the alluvial solls of the valley and especially on river bottoms. The Beurre Hardy is considered a good commercial sort and by all means a tree or two should be found in all family orchards. Ripens in September.

Doyenne du Comice Owing to the late blooming and the early bearing of this variety, it is considered by many orchardists as the money maker among pears.

The tree is a vigorous grower and a regular bearer. The fruit is large, and of roundish shape, tapering to the stem; the skin is waxy yellow in color, covered with a light crimson blush. The flesh is white, fine grained, smooth, juicy and has a delightful aroma. Owing to the fine keeping and carrying qualities, some experienced orchardists claim this variety equal to the much favored Bartlett. Ripens in October.

Easter Beurre The fruit is large, with a skin of yellowish green, sprinkled with many russet dots and often more or less covered with russet. The flesh is white, fine grained, melting and juicy, with a very rich, sweet flavor. Ripens in October.

Glou Morceau Is a very fine pear for table and all commercial uses, being of fine flavor and an excellent shipper. Fruit is large, of a greenish yellow color, splashed with russet.

The flesh is white, very fine grained, sweet and buttery, which makes it a great favorite, especially for family uscs. Ripens in December.

Seckel The Seckel pear, or Summer Seckel, as it is often called, is known to many pear growers throughout the East and West as one of the richest and most exquisitely flavored varieties in existence.

The fruit, while small, is regularly formed, having a skin of brownish green at first with a lively russet red cheek. The flesh is whitish, buttery, very juicy, containing a rich spicy flavor and aroma.

No family orchard is complete without one or more of these trees. Ripens in August, but can easily be kept until September.

Winter Nelis Winter Nelis is held in very high esteem by experienced pear orchardists in general. It is without exception the finest winter variety yet produced.

The tree is very hardy and a very heavy cropper. Fruit is of medium size and roundish in appearance, yellow in color, covered with russet. The flesh is yellow, sweet and fine grained. Unexcelled for quality when fully ripe. Owing to the fine keeping qualities of this pear, it is unexcelled as a good shipper.

Ripens in December.

\section{PLUMS}

The plum is one of the most attractive fruits to be found in the markets. Their beautiful color and flavor make them particularly valuable for marketing fresh as well as for canning and the making of jelly and jam.

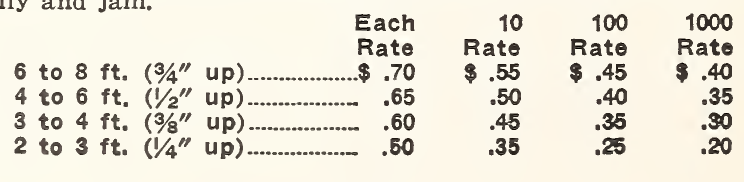


Beauty Is of exceptional value for shipping to Eastern markets, as the fruit, when picked green, will color up and develop its delicious flavor later. Owing to its earliness, showy appearance and size, which runs from two to two and one-quarter inches in diameter, it commands the highest prices on all markets.

The fruit is decidedly heart shaped and for this reason makes an easy and attractive pack. The skin being a beautiful crimson color, freely sprinkled with whitish dots, presents a fine appearance on the market. The flesh is amber in color, permeated with crimson. Ripens early June.

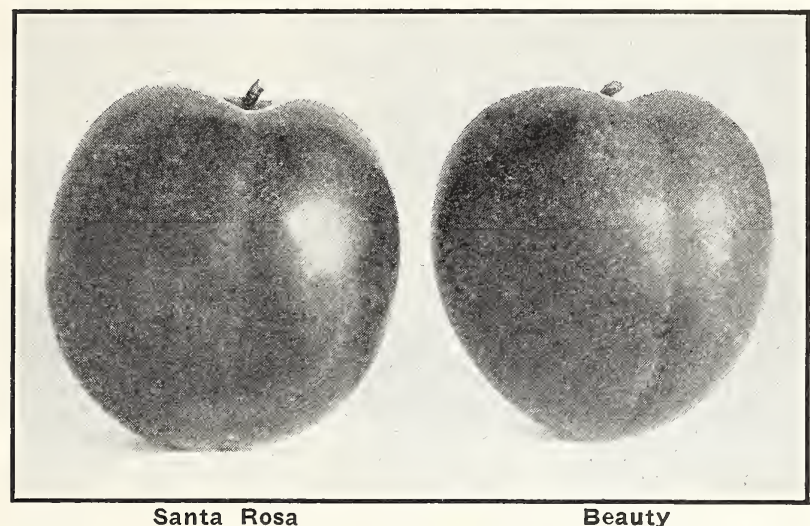

Burbank Is considered one of the best of the Japanese type. The fruit is large, bright red in color, slightly mottled with yellow. Flesh is rich yellow, juicy and very sweet.

Owing to the early age at which this tree bears and its usual productiveness, it is considered by orchardists as well as many fruit shippers to be a good variety. Ripens last of June.

Climax This variety was originated by Luther Burbank, of Santa Rosa, California, and on account of its early ripening period and its good shipping and market qualities is one of the most profitable plums grown in California.

The fruit of the Climax is quite large, heart shaped, and a very dark red in color. The flesh is yellow and of good flavor.

When planted in large acreage, orchardists have experienced no trouble in disposing of the crops at good figures for shipment to Eastern markets. Ripens middle of June.

Damson This variety enjoys the distinction of being more widely planted and better known to planters of home orchards than any other plum. Its qualities for the making of preserves, jellies, pies, dumplings, etc., are unequaled by any other plum.

The fruit is small, oval in shape, with a purple skin covered with a thick blue bloom. The flesh is tart and separates readily from the pit.

We particularly recommend this plum for home use. Ripens in September.

Formosa The fruit is heart shaped, uniform in size, averaging in circumference six inches one way to seven and onehalf the other way. The skin is of a light cherry red color with a very pale bloom changing when fully ripe to a rich deep red. The flesh is of a delicate yellow, firm, juicy and very delicious. Ripens in June.

Grand Duke The fruit is very large and attractive, having a dark skin, almost black, covered with a deep blue bloom. The flesh is firm, with a yellow tinge, and has a slight tendency to cling to the pit. Its time of ripening and also its attractive appearance make it a very valuable plum for shipment to the Eastern market.

The Grand Duke is also very valuable as a pollenizer for the Tragedy.

Green Gage The fruit is of medium size, of yellowish green color, often dotted or marbled with red. The flesh is pale green, exceedingly juicy, melting, and decidedly free from the pit.

We particularly recommend this variety for commercial as well as home planting. Ripens about the middle of August. 

Kelsey Japan The Kelsey plum is of Japanese origin and has Its size and good keeping qualities have made it a favorite among the late shipping varieties.

The flesh is yellow, very firm, and adheres slightly to the pit. Ripens July to September. Santa Rosa Is one of the best of the late Burbank introduc-
tions, and, owing to its large oval shape and beautiful purplish crimson color it is an excellent plum for shipping purposes. The plum is large and uniform in size. Skin purplish crimson color with a pale yellow bloom. Flesh is yellow, streaked and mottled with red, juicy and of rich flavor. Ripens June and July.

Satsuma The fruit is large and almost round and of a deep, dark red color. Flesh is firm, blood red, juicy and of good flavor, with a very small pit. The tree is a strong grower and a heavy producer. It ripens July to September.

Tragedy Beautiful dark purple in color, being elongated in Tragedy shape; flesh is of a yellowish green, very rich and juicy; its early ripening has also much to do with making it a favorite among prune and plum growers. While it is particularly adapted for shipping purposes, on account of its good carrying qualities, it also makes a fair dried product. Ripens early July.

Wickson The fruit of Wickson resembles the Kelsey in a great many ways, but is more symmetrical and when ripe ranges from a deep cherry red to a rich scarlet. The flesh is of an amber tinge and quite juicy, with a very small pit, and is valuable for its long keeping qualities. Ripens in August.

Yellow Egg Is often called the Egg Plum on account of its its canning qualities.

shape. It is very popular and highly regarded for

Fruit is of large size, often measuring as much as six inches by its longest circumference. The skin is yellow, often bearing white dots, covered with a thin white bloom. Flesh yellow, rather acid, but becoming sweet when fully ripe, and has a tendency to cling to the pit. Ripens July and August.

\section{PRUNES}

\section{PRUNES-(Excepting Burton)}

\begin{tabular}{|c|c|c|c|c|c|}
\hline & & $\begin{array}{l}\text { Each } \\
\text { Rate }\end{array}$ & $\begin{array}{r}10 \\
\text { Rate }\end{array}$ & $\begin{array}{r}100 \\
\text { Rate }\end{array}$ & $\begin{array}{r}1000 \\
\text { Rate }\end{array}$ \\
\hline 6 to $8 \mathrm{ft} .\left(3 / 4^{\prime \prime}\right.$ & up) $\ldots \ldots$ & $\$ .65$ & $\$ .50$ & $\$ .40$ & $\$ .35$ \\
\hline 4 to $6 \mathrm{ft} .\left(1 / 2^{\prime \prime}\right.$ & up) ............... & .60 & .45 & .35 & .30 \\
\hline 3 to $4 \mathrm{ft} .\left(3 / 8^{\prime \prime}\right.$ & $u p)$ & .55 & .40 & .30 & .25 \\
\hline 2 to $3 \mathrm{ft} . \quad\left(1 / 4^{\prime}\right.$ & $u p)$ & .50 & .35 & .25 & .20 \\
\hline
\end{tabular}

Price on Burton Prunes 10c Per Tree Higher

Burton The tree is a strong, vigorous, upright grower; a consistent and regular bearer of good crops. The fruit in type is like the French Prune but in size is the largest and best drying prune yet produced. The skin is a rich violet-purple covered with a light blue bloom; flesh a rich golden yellow, fine grained, tender, sweetly acidulous, aromatic and sprightly. The pit is small when compared to the immense size of the fruit, which averages 20-30 to the pound. Ripens middle of August and September.

Double X French A large prune, having much the same texture and flavor as the comnion French Prune; but on account of its large size, it is much more valuable as a commercial variety. Also very fine for canning. 
French Improved The French (or Petite d'Agen) enjoys the reputation of being more widely grown in California than any other prune.

The tree is a very vigorous grower, and bears abundantly in almost all sections of the State. The fruit is of medium size, egg shaped, has rather a thin neck and a deep violet color. The flesh is of good quality, sweet, and very sugary. It certainly has no equal as a drying prune.

\section{Imperial Epineuse}

Fruit is large, uniform and of a beautiful violet purple color, with a dark b I u e bloom. The flesh is of a greenish yellow, very sweet, and contains a small pit. The fruit when dried is considered superior to all o $t h$ er varieties in size, flavor and sweetness. Owing to the high quality of this fruit, we feel that we should particularly recommend it. Ripens August and September.

\section{Robe de Sargent $\begin{gathered}\text { The } \\ \text { fruit }\end{gathered}$} is of a large oval shape, having a skin of deep purple color, being nearly black $\mathrm{w}$ he $\mathrm{n}$ fully ripened and covered with a blue bloom. Flesh is of a greenish yellow color, and possesses a fine sweet flavor. The fruit when dried is nearly always classed as fancy and brings the highest price to be obtained on the market.

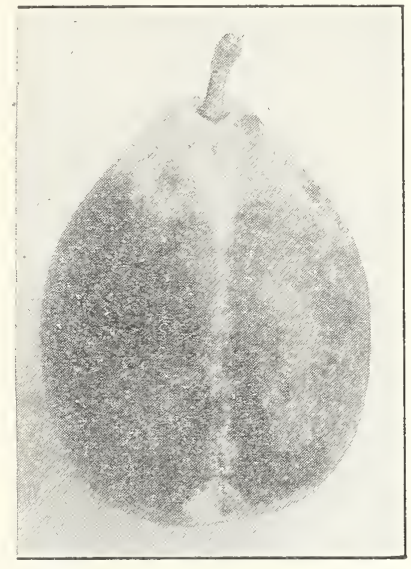

French Improved

Standard A variety originated by Luther Burbank, of Santa Standard California, and is a cross between the Sugar and Tragedy.

It is of large size, purple in color, overspread with a thick blue bloom. Flesh is amber, fine grained and of good flavor. In addition to making a fine dried product, it is also a good shipper. Ripens middle of August to middle of September.

Sugar The tree is a very strong and vigorous grower and a heavy Sugar bearer. The skin is of a dark purple color and overspread with a white bloom. Flesh is yellow and very rich.

On account of the abundance of sugar contents in this fruit and its early period of ripening, we do not hesitate to say it is one of the very best for both shipping and drying purposes. It dries rapidly and weighs heavy. Ripens about the first of August.

\section{PERSIMMONS}

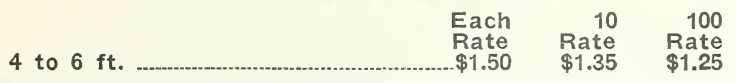
Hachiya Tree is a very vigorous grower, of upright habit and
very shapely. The fruit is pronounced by growers of persimmons as the largest and finest specimen of all persimmons, and of extremely high quality.

It is of oblong shape, has rather a short point, and a skin of bright dark red, covered with dark blotches. Ripens October.

\section{POMEGRANATES}

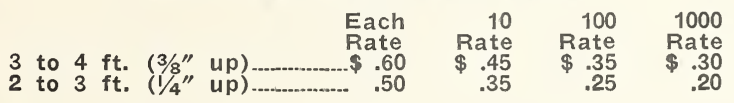

Wonderful The fruit is of yellow color overspread with red and often blushed with deep scarlet. The pulp is a rich garnet color, with an abundance of juice, of a dark color and a very pleasing flavor, slightly sub-acid. Ripens in October. 


\section{QUINCES}

Quince trees are planted mostly in the family orchard, but of late years quite an acreage has been planted for Eastern shipment and for canning.

The Quince when preserved has a fine flavor and is a very attractive fruit.

The tree being of a dwarf type comes into bearing earlier than almost any other fruit tree.

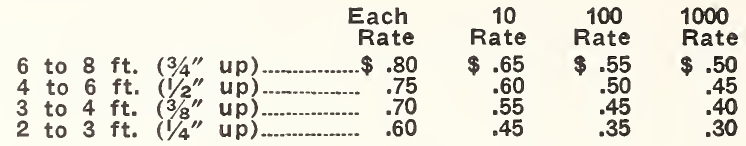

Apple or Orange The former part of the name of this variety resembles very much that of the apple; the latter on account of it color, which resembles that of the orange.

The fruit is of a fine golden color when ripe, having a smooth skin. The flesh is golden yellow in color, fine and of excellent flavor, highly recommended for the making of preserves. Suitable for planting in all fruit sections of this State. Ripens August and September.

Pineapple Originated by Luther Burbank, of Santa Rosa, California, about the year 1899 .

The Pineapple Quince was so named on account of its very high quality and unsurpassed pineapple flavor. The fruit resembles an apple in appearance and is smooth, globular, of a light golden yellow. The flesh is white and will cook tender in five to ten minutes. Ripens late August.

Smyrna The tree is a strong, vigorous grower, possessing an abundance of foliage, which makes it very attractive from an ornamental standpoint, as well as affording ample protection for the fruit.

The fruit is large and of beautiful lemon color. Flesh is tender with a delicious flavor and is an excellent variety for the making of preserves and jellies.

It is also conslaered valuable for market purposes on account of its attractive color and its good keeping qualities. Suitable for planting in all parts of California. Ripens September to October.

\section{ALMONDS}

The Almond is one of the most favored nuts grown and commands good prices commercially. In some sections they have been planted very extensively, but they do well in almost all sections of California. All family orchards should contain two or three Aimond trees.

When pranting I. X. L., Ne Plus Ultra or Nonpareil, the planter should always interset with Texas Prolific or Drake Seedling, as the pollination of Almond trees is a very important matter.

\begin{tabular}{|c|c|c|c|c|}
\hline & $\begin{array}{l}\text { Each } \\
\text { Rate }\end{array}$ & $\begin{array}{r}10 \\
\text { Rate }\end{array}$ & $\begin{array}{r}100 \\
\text { Rate }\end{array}$ & $\begin{array}{r}1000 \\
\text { Rate }\end{array}$ \\
\hline to $6 \mathrm{ft} .\left(1 / 2^{\prime \prime}\right.$ up $)$ & $\begin{array}{r}.65 \\
.60 \\
50\end{array}$ & $\$ .50$ & $\begin{array}{r}.40 \\
.35 \\
.25\end{array}$ & $\begin{array}{r}\$ .35 \\
.30\end{array}$ \\
\hline
\end{tabular}
Drake Seedling Originated on the grounds of Mr. Drake, of and a heavy bearer; in fact, it has the reputation of bearing regularly in all sections. One reason for its heavy bearing is the fact that it is very late in blooming, consequently is more free from frost than any other variety.

I. X. L. The tree of the I. X. L. is a sturdy upright grower, producing large nuts which are very easily hulled. The shell is soft and smooth; the kernel is large and very plump.

One of the features which makes this variety in demand is the fact that the shell possesses a fine color without bleaching. This variety always brings a high price in all markets and to our knowledge has never been lower in price than second in the entire list of almonds. 
Ne Plus Ultra The tree is a strong grower and inclined to have a drooping habit.

The nut is long and narrow in shape and has a soft shell. The kernel is very large, sweet and highly flavored. Hulls freely and is considered a favorite among almond growers for commercial purposes. Blooming period middle of March. Nonpareil The Nonpareil has probably been more largely tree is a very strong grower, inclined to be of a weeping habit, and on account of its fine foliage presents a very beautiful appearance. It has the reputation among almond growers, in all sections where grown, as being a heavy and regular bearer.

The nut is large, long and narrow, having a thin shell and a good color. The kernel is long, fills the shell well and possesses an excellent flavor. It commands the highest prices on the market, selling from one to three cents higher than other varieties.

We highly recommend the Nonpareil for planting in all almond sections of California. Blooms last week in March.

Texas Prolific The tree is equal to that of the Drake's Seedling for its heavy bearing qualities, but grows much larger. It is of an upright habit, having a smooth wood and a fine foliage. It is a late bloomer, consequently is almost sure to escape damage from late frosts. The nut is of medium size, having a soft shell, which is white in color. The kernel is short, plump and very sweet. Its value as a pollenizer must not be overlooked. Blooms last of March.

\section{WALNUTS}

Walnuts do well in practically all sections of California, and in some sections they are grown extensively with very profitable results.

Our Walnuts are all grafted on the California Black root.

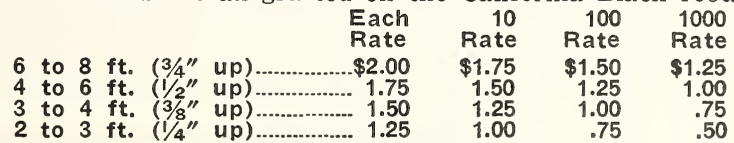

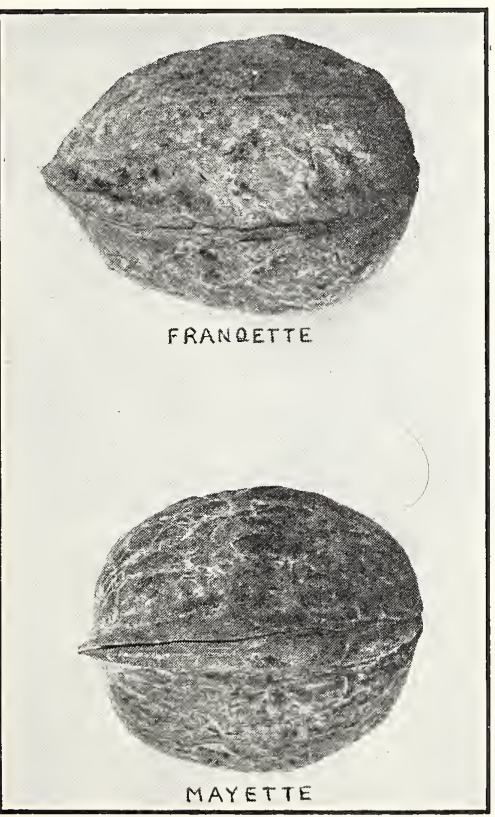

Eureka The tree is a strong upright grower and a heavy producer. The nuts are of large size, soft shell smooth in appearance and highly valued for commercial purposes. The kernel cial purposes. The kernel is of good color, plump. and very rich in flavor.

Franquette Is more widely known and planted throughout the different walnut sections of California, O r e $\mathrm{g}$ o $\mathrm{n}$ and Washington than any other variety.

The tree is a $\mathrm{strong}$ grower and a very proliflc bearer. The nuts are of large size, long and smooth. The shell is of medium thiciness, bearing a full. sweet and very rich kernel of high flavor.

Mayette The tree blooms late in the spring and is a very heavy bearer. The nuts are large, uniform and inclined to be flattened at the base. The shell is of a light color, soft and contains a plump kernel of very fine flavor, always commanding the highest market price.

For pollination purposes it is advisable to plant it with the Franquette, as both trees will then bear more abundantly than if planted alone. Payne's Seedling A very promising new variety, and does exramento Valleys. The tree is a vigorous grower and comes into bearing at an earlier age than any other variety. It produces good crops of very fine nuts. 


\section{Price of Seedling Walnut Trees}

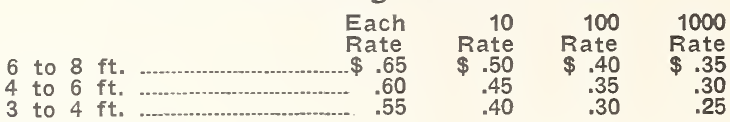

California Black The tree grows to an exceptional size, is very hardy, and considered very valuable for its wood, which is used largely for cabinet making. The nut is of medium size, has a very hard shell, and possesses a plump kernel, which has a fine rich flavor.

It is planted quite extensively in some sections as an ornamental shade tree and is well adapted for this purpose.

\section{OLIVES}

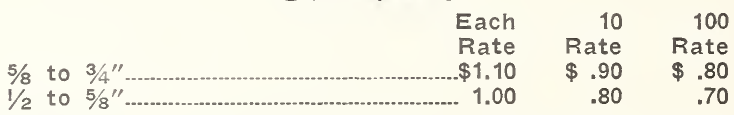

Manzanillo The Manzanillo olive was introduced from Spain and is one of the most highly recommended and extensively planted of all varieties. The tree is a strong grower of a decided weeping habit.

The fruit of the Manzanillo is large, oval in form, and has a distinct tit at the lower end and is almost black when fully ripe. It is highly recommended for the making of green and ripe pickles, as well as for the making of oil. Ripens early in October.

Mission Is one of the oldest and best varieties of olives known. The tree grows large; is a heavy producer, and very ornamental. The fruit is medium to large, and while oblong in shape, is more round on the lower end than the Manzanillo. Flesh is very firm and is highly recommended for the making of both green and ripe pickles, as well as oil. Ripens late in October.

\section{ORANGES}

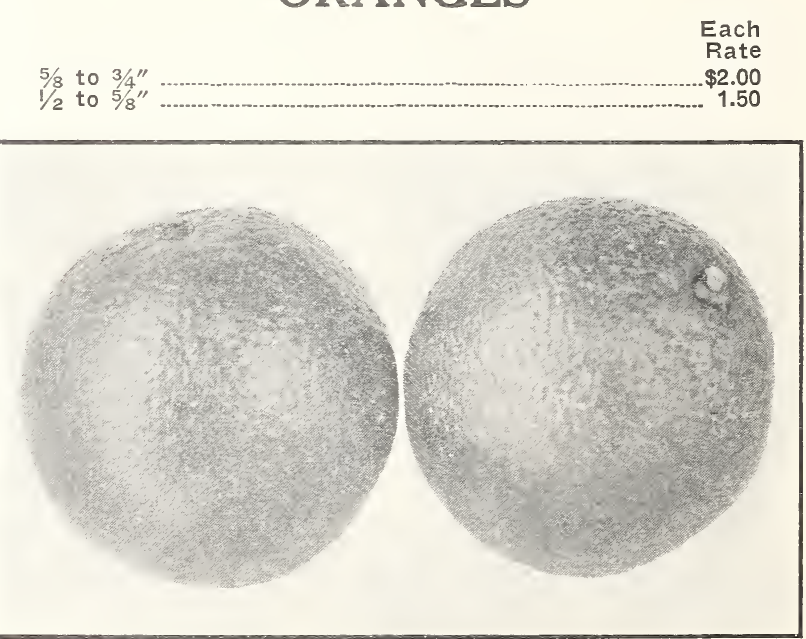

Washington Navel This is the leader of all California oranges. It is said to derive its name from the fact that it was first grown in Washington and also from the peculiar formation of the blossom end of the fruit.

The more this variety has been cultivated and exhibited the more popular it has become until now it is classed as the queen among oranges, and is more widely grown than any other variety.

The tree is a strong, rapid grower and a prolific bearer. The fruit is medium to large, juicy, possessing a fine flavor and so few seeds are ever discovered that it is termed as seedless.

Valencia Late Is the leading summer orange. The fruit is large, oblong, firm and juicy, with very little rag. Ripens late, reaching the markets when all other varieties are gone, thus commanding the best of prices.

Fruit ripens in June, but will remain on the tree in good condition as late as September. 


\section{LEMONS}

$1 / 2$ to $5 / 8$...... $\quad \begin{array}{r}\text { Each } \\ \text { Rate } \\ \$ 1.50\end{array}$

Eureka Bears the reputation of being more widely grown in California than any other variety of lemons.

The tree is a vigorous grower and unlike other varieties is practically free from thorns. The fruit is of medium size, smooth, glossy and an excellent keeper. In many sections of the State it blooms and sets lemons all the year around.

This is a very attractive feature of the Eureka, as lemons are usually much in demand during the summer months and at this period it might be said the Eureka produces more lemons than at any other. It is also regarded as very valuable in sections where frost sometimes occurs on account of its having several crops.

Aside from its strong growing and heavy bearing qualities, it is highly ornamental, as there is no other variety of fruit which blossoms and bears fruit at the same period of the year.

\section{GRAPE FRUIT}

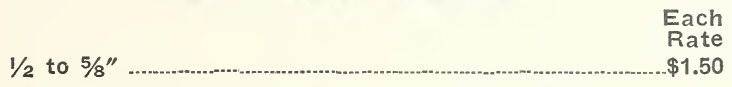

Marsh's Seedless While there are other varieties of Grape Fruits grown, the Marsh's Seedless is so much superior in quality and size, that many Nurserymen have deemed it advisable, on account of the heavy demand for this sort and the small amount of inquiries for others, to propagate it only.

The fruit is large, skin very smooth, beautiful light yellow color when ripe and hangs on the tree well. The pulp is juicy and contains very little rag.

\section{GRAPES}

Write for special quotations on large quantities

TABLE VARIETIES

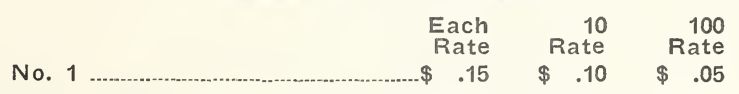

Black Cornichon $\begin{aligned} & \text { Berries very large and oblong, almost black. } \\ & \text { September. }\end{aligned}$

Emperor Berries large, oval, deep red; clusters large. October.

Flame Tokay Large, handsome bunches; berries large, flame

Fresno Beauty Berries large, round, dark purple; bunches

Malaga Berries large, oval; yellowish green color. August.

Red Malaga Berries oval and large, deep red; bunches long: and loose. September.

\section{SPECIAL TABLE VARIETIES}

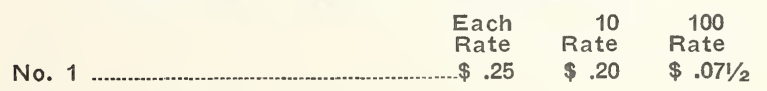

Almeria Bunches large and loose shouldered; berries large, oval, yellowish green; excellent keeper. October.

Black Monukka Berries black, seedless, medium size; bunches loose and large. July.

Olivette Blanche (Lady Finger) Bunches large; berries unusually long, yellowish green. September.

Olivette de Vandemain Closely resembles the Almeria. Oc-

Ribier Berries very large, round, dark purple; medium bunches.
Middle of August. 


\section{WINE VARIETIES}

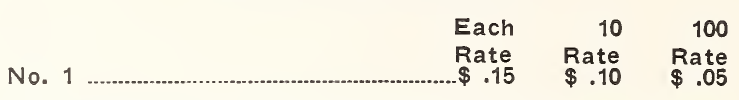
Alicante Bouschet $\begin{aligned} & \text { Strong grower; bunches medium size; su- } \\ & \text { perior bright red color. September. }\end{aligned}$

Black Malvoise Berries large, oblong, reddish black. Fine table and wine grape. September.

Carignan Berries medium, slightly oblong, black; bunches Grenache Bunches long; berries black and very juicy. September.

Mission Bunches large; berries round, purple black. September.

Rose of Peru Bunches large and loose; berries black, round and

Zinfandel Bunches large and compact; berries round, dark

\section{RAISIN VARIETIES}

$\begin{array}{rrrr} & \begin{array}{r}\text { Each } \\ \text { Rate }\end{array} & \begin{array}{r}10 \\ \text { Rate }\end{array} & \begin{array}{r}100 \\ \text { Rate }\end{array} \\ \text { No. } 1 & \$ .15 & \$ .10 & \$ .05\end{array}$

Muscat Bunches large and loose shouldered; berries large, yellowMuscat ish green; decided flavor; excellent eating and raisin grape. August.

Sultana Bunches large and compact; berries round, greenish yel-

Thompson Seedless Berries oval, greenish yellow; no seeds. August.

\section{EASTERN VARIETIES}

No. $1 \quad \begin{array}{rr}\text { Each } \\ \text { Rate }\end{array} \quad \begin{array}{r}10 \\ \text { Rate } \\ \$ .20\end{array}$
Concord Berries large, round; glossy black color Most popular
Eastern variety. August.

\section{THE BERRY FRUITS}

\begin{tabular}{|c|c|c|c|}
\hline & Each & 10 & 100 \\
\hline Cory's Thornless Blackberry... &.$\$ .25$ & $\$ 2.00$ & $\$ 12.50$ \\
\hline Dewberry & .20 & 1.50 & 10.00 \\
\hline Gooseberry ................. & .30 & 2.50 & 20.00 \\
\hline Loganberry & .20 & 1.50 & 10.00 \\
\hline Raspberry & .20 & 1.50 & 10.00 \\
\hline Currant & .30 & 2.50 & 20.00 \\
\hline Banner Strawberry & $\ldots$ & .30 & 2.00 \\
\hline Marshall Strawberry & .... & .30 & 2.00 \\
\hline \multicolumn{2}{|r|}{ Each } & $\begin{array}{r}10 \\
\$ \quad 30\end{array}$ & $\begin{array}{r}100 \\
\$ 2.00\end{array}$ \\
\hline RHUBARB.. & .25 & 2.00 & 15.00 \\
\hline
\end{tabular}




\section{Ornamental Department}

We are listing herein a few of the best ornamentals, deciduous and evergreen; also shade trees-varieties that are best adapted for street plantings, highways, school and home grounds throughout the Pacific Coast.

The planting of ornamentals and shade trees is a decided improvement to any home and lends an attractive appearance to any city.

\section{DECIDUOUS TREES}

Balm of Gilead One of the strongest growers and most largely planted varieties of poplars. It grows very tall and handsome, has a broad crown and spreading habit. Large, green, heart-shaped leaves and a medium smooth bark. To those desirous of securing a fast growing avenue or yard shade tree we highly recommend this variety.

$\begin{array}{rrrr}6 & \text { to } 8 \mathrm{ft} & \text { Each } & 10 \\ 8 \text { to } 10 \mathrm{ft} & & & 1 . \\ 10 & \text { to } 12 \mathrm{ft} & & \\ \end{array}$

\section{Elm, American}

Magnificent tree. Native from the Pacific to the Atlantic. Erect grower. Attains height of 120 feet.

Each

4 to $6 \mathrm{ft} . \$ .75$

6 to $8 \mathrm{ft}$... 1.00

8 to $10 \mathrm{ft}$... 1.25

10

$\$ 6.00$

7.50

10.00

\section{Peach, Flowering}

This is one of the most attractive trees to be found in the e a r ly spring and should be planted in all parks and yards where flowers are appreciated.

In April it will be found laden with blossoms before the leaves appear.

The flowers are large, double and very fragrant. We propagate these flowering peaches in the double red and double pink.

4 to $6 \mathrm{ft}$.

Each

3 to $4 \mathrm{ft}$. $\$ .75$ .60

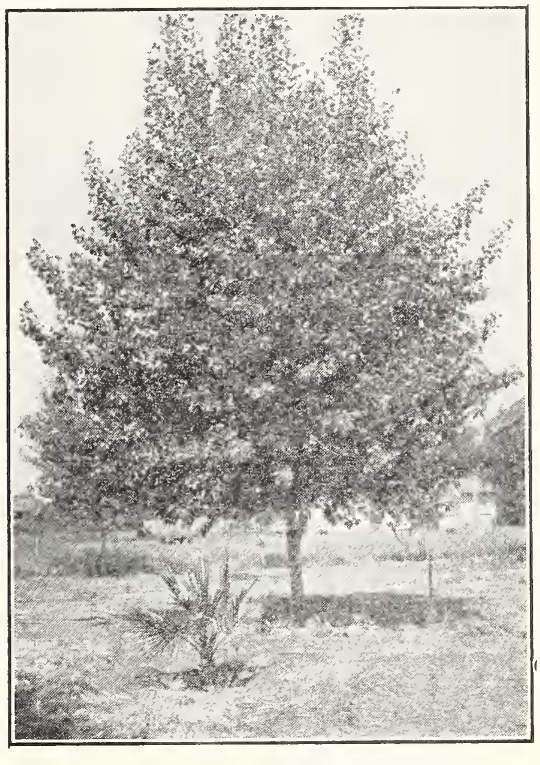

Balm of Gilead

Quince Flowering "Japan Scarlet Quince"-Flowers brilliant Quince Flowering scarlet; foliage bright glossy green. Makes a beautiful flowering hedge. 2 to $3 \mathrm{ft}$. $\$ 1.00 \mathrm{Each}$

Sycamore, European Is known also as the Oriental Plane tree, is a native of Europe and Asia, and is regarded as one of the best varieties for street, avenue and yard planting. It is of spreading habit with a well-rounded head, having plenty of foliage to protect the bark from sunburn. Leaves are very large and dark green in color.

The tree can easily be recognized on account of its bark, which is very thin and peels off in irregular flakes, leaving the trunk patched with light and dark spots.

We highly recommend planting it in all sections of California and particularly in the San Joaquin Valley.

$\begin{array}{rrrr}6 \text { to } 8 \mathrm{ft} & \text { Each } & 10 \\ 8 \text { to } 10 \mathrm{ft} & \$ 1.25 & \$ 10.00 \\ 10 & \text { to } 12 \mathrm{ft} .\end{array}$


Texas Umbrella The Texas Umbrella was discovered in Texas, near San Jacinto, and was found to be so much superior to other varieties of umbrella trees that it has been more largely planted than any other.

The branches are erect, the foliage of drooping habit, which gives the tree the appearance of a large umbrella. It enjoys the distinction of giving the best dense shade possible to obtain. The foliage is of a bright dark green and produces flowers of a lilac color, which are very fragrant. It also produces berries or seeds which very much resemble beads and are often used for stringing as beads.

This variety is particularly adapted to the warmer climates in California and while it is not as highly recommended for street planting as some other shade trees, we certainly do not hesitate to recommend it for all home yards, avenues and any place where dense shade is desired.

$\begin{array}{rrrr}4 \text { to } 6 \mathrm{ft} & \text { Each } & 10 \\ 6 \text { to } 8 \mathrm{ft} & \$ .75 & \$ 6.00 \\ 8 \text { to } 10 \mathrm{ft} & 1.50 \\ & & 1.00 & 7.50\end{array}$

\section{EVERGREEN TREES}

Acacia Baileyana One of the very best. A strong grower. divided. In the early spring the tree is covered with beautiful lemon-yellow flowers.
Potted, 3 to $4 \mathrm{ft}$.
Each
10
$\$ 7.50$

Acacia Melanoxylon Widely known throughout California as the "Black Acacia" and more widely planted for street use than any other variety.

It is a beautiful pyramidal grower, having large oblong leaves of a dark green color and flowers of a light yellow color. It is very valuable for street planting and is especially adapted for planting in parks, where it often attains the height of seventy-five feet.
Each
10
Potted, 4 to $5 \mathrm{ft}$.
$\$ .75$
$\$ 6.00$

Acacia Mollissima $\begin{aligned} & \text { Is one of the best of the feathery foliage } \\ & \text { varieties. }\end{aligned}$

The tree is a strong grower and on account of its heavy foliage and its extensive crop of beautiful yellow flowers it is somewhat inclined to droop and grow rather crooked. For this reason we do not particularly recommend it as an avenue or street tree. We, however, believe that in every yard or space that can be found, one of these beautiful flowering Mollissima Acacias should be planted.

$\begin{array}{rr}\text { Each } & 10 \\ \text { Potted, } 4 \text { to } 5 \mathrm{ft} . & \$ .75\end{array}$
Cedrus Deodara Known as the Himalayan or Indian cedar, and has an abundance of drooping branches with a beautiful silvery green foliage. It is pyramidal in shape and often attains the height of 120 feet.

It is often described as being a tree of grace and beauty. Largely found in parks and in many front yards, and on account of its extreme beauty and hardiness, in California, we highly recommend its planting.

Balled, 2 to $3 \mathrm{ft}$. $\$ 2.50$ Each

Balled, 3 to $4 \mathrm{ft}$. $\$ 3.50$ Each

Cypress, Arizona Handsome tree with briliant silvery blue branches. foliage. Growth rather compact with stout

$\begin{array}{lrrr} & & \text { Each } & 10 \\ \text { Balled, } 3 \text { to } 4 \text { ft. } & \$ & \$ 2.50 & \$ 22.50 \\ \text { Balled, } 4 \text { to } 6 \text { ft. } & -3.00 & 25.00\end{array}$
Cypress, Italian A tall, very slender, tapering tree with erect for architectural effect.

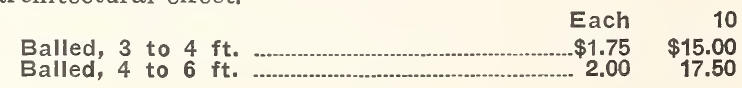


Oleander This is one of the best known evergreen ornamentals throughout the central and southern sections of California, where it does exceptionally well. The foliage is of a long shape, being light green in color. Its long blooming period, during which it produces an abundance of beautiful flowers, makes it one of the most highly recommended for avenue planting. We can supply Oleanders in white, red and pink.

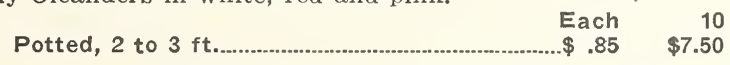

Pepper Tree Round-headed tree with low, drooping branches. Leaves pinnate with acute leaflets. Foliage very pungent-aromatic. Flowers very small, but very numerous, greenish white, very attractive to bees. Berries rosy red, in long, drooping clusters during the winter.

Potted, 3 to $4 \mathrm{ft}$. $\$ .75$ Each

\section{DECIDUOUS SHRUBS} Crape Myrtle Is a native of Europe and one of the most beauti-
ful shrubs to be found in California. It often grows to a height of ten feet; has a very fine foliage and bears an abundance of deep pink flowers. It is very much favored by landscape gardeners for grouping with other plants both for park and home ground purposes. It thrives exceedingly well in almost all sections of California.

2 to 3 feet $\$ 1.00$ Each

Hydrangea This is one of the most fascinating flowering plants to be found throughout the summer season. It often grows to a height of eight feet, commences blooming in early August and lasts until the first frost. The flowers are large and of pure white color, changing to a pink or bronze color.

Balled, $1 \frac{1}{2}$ to $2 \mathrm{ft}$.

$\$ 1.50$ Each

Lilac (Syringa) There are probably no other flowering shrubs which are so largely planted throughout the East and West as the purple lilac. Its sweet fragrance, heavy blooming qualities and fine foliage are certainly a great attraction when planted in parks, yards or almost any place where one desires an ornamental shrub.

2 to $3 \mathrm{ft}$. $\$ .75$ Each

Snowberry Slender shrub of spreading, arching growth, bearing small pink flowers and showy clusters of very large, clear white berries at ends of branches.

3 to $4 \mathrm{ft}$.

$\$ 1.00$ Each

Spirea (Bridal Wreath) A beautiful low growing shrub and an Spirea (Bridal Wreath) abundant bloomer. The flowers are white, very compact and grow in clusters. It is one of the earliest blooming shrubs, and highly recommended for park and yard planting.

3 to $4 \mathrm{ft}$.

.. .75 Each

\section{EVERGREEN SHRUBS}

Abelia grandiflora Free-flowering shrub with small, opposite, glossy green leaves. Flowers are tubular, almost an inch long, white flushed lilac pink. Blooms profusely and continuously all summer.

Balled, 2 to $3 \mathrm{ft}$. $\$ 1.75$ Each

Balled, 3 to $4 \mathrm{ft}$. 2.00 Each

Arbor Vitae, Golden Dwarf, compact shrub; bright yellow foliage, retaining its wonderful color and form under all conditions; well adapted to garden and porch ornamentation.

Balled, 1 to $2 \mathrm{ft}$.

$\$ 2.50$ Each

California Holly (Christmas Berry)

Our well-known native shrub; the glory of our hills and canyons in early winter when loaded with its brilliant red berries.

Potted, 2 to $3 \mathrm{ft}$. $\$ 1.25$ Each 

California Privet A strong growing shrub, with bright green, priced hedge plants. Can be kept trimmed at any height.

3 to $4 \mathrm{ft}$.

$10 \quad 100$

Cotoneaster horizontalis One of the best trailing shrubs.

$\mathrm{Branches}$ grow almost on the ground. Leaves very small and turn red during winter. Flowers pinkish white. Berries bright red and borne in great profusion.

Balled, $11 / 2$ to $2 \mathrm{ft}$.

$\$ 2.25$ Each

Cotoneaster pannosa Very beautiful shrub of upright growth. Branches long, slender and slightly arching, covered with purplish mahogany bark. Leaves deep, rich green above and covered with silvery down beneath and along edges. Flowers white. Red berries borne in great profusion in the fall, which can be cut and kept in water for weeks.
Potted, 4 to $5 \mathrm{ft}$
$\$ 1.00$ Each
2.50 Each

Balled, 5 to $6 \mathrm{ft}$.

Erica Mediterranea One of the most popular Heaths. shrub with dark green leaves. In winter it is covered with tiny pink flowers.

Balled, $11 / 2$ to $2 \mathrm{ft}$.

$\$ 1.50$ Each Erica Melanthera Another splendid winter-blooming Heath. ing, black-tipped stamens.

Potted, 1 to $11 / 2 \mathrm{ft}$.

$\$ .75$ Each Evonymus Japonica Fine, upright shrub of moderate size and are clear, dark green. Has many variegated forms.

Balled, 2 to $3 \mathrm{ft}$.

$\$ 1.50$ Each

\section{Evonymus aureo marginatus Of dwarf and compact} green. Leaves deep yellow towards the edges, blotched in the center with light and dark green.

Balled, $11 / 2$ to $2 \mathrm{ft}$.

$\$ 2.00$ Each

Laurustinus A strong evergreen shrub which is highly valued as a hedge plant as well as for individual planting. Leaves are rather long and a dark green color. Bears an abundance of flowers in broad heads, pinkish in the bud, white when fully opened.

Balled, 2 to $3 \mathrm{ft}$

$\$ 1.50$ Each

\section{Mahonia (Oregon Grape)}

Well-known native shrub of medium size, with dark green leaves, which become coppery purple during winter. New growth very glossy. Flowers bright yellow, in slender, erect, clustered racemes, followed by a profusion of dark blue berries.

Balled, 2 to $3 \mathrm{ft}$.

$\$ 1.50$ Each

Myrtus Communis A beautiful shrub, valuable for either single specimens or small hedge. Follage is a glossy green and highly aromatic. Bears small white flowers, followed by black berries. Succeeds well in hot, dry situations.

Balled, $1 \frac{1}{2}$ to $2 \mathrm{ft}$
Balled, 2 to $3 \mathrm{ft}$.

$\$ 1.00$ Each

Nandina A very handsome shrub of moderate size and rather slow growth. The leaves are much divided, with large leaflets, light green in summer, turning to a vivid red during the fall and winter. The white flowers are small, in good-sized, erect panicles, followed by bright crimson berries.

Potted, $11 / 2$ to $2 \mathrm{ft}$. 
Pyracantha Coccinea (Burning Bush) A beautiful Poliage

Potted, 1 to $11 / 2 \mathrm{ft}$.

$\$ 1.00$ Each

Balled, 2 to $3 \mathrm{ft}$.

2.00 Each

Pyracantha Crenulata Earliest of red-berry-bearing slender, leaves long, narrow and glossy. Flowers white, berries bright red. Excellent for hedge.

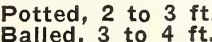
$\$ 1.00$ Each
2.50 Each

Spanish Broom An upright growing shrub; flowers yellow, proround, leafless branches.

Potted, 3 to $4 \mathrm{ft}$.

$\$ 1.00$ Each

\section{CLIMBING PLANTS} Ampelopsis Quinquefolia More widely known as the "Virstrong, vigorous grower, having a large leaf of a beautiful green color, becoming a gorgeous golden coppery color in the $\underset{\text { Each }}{\text { autumn. }}$

Potted

$\$ .75 \$ 6.50$

Ampelopsis Veitchii Commonly known throughout California "Boston Ivy."

In the coast sections as well as the interior hot sections of California, this variety can often be found, covering large brick schools and other buildings, clinging to the brick or stone work without any support.

The vine is a very rapid grower, having a foliage of a beautiful glossy green color, changing to a golden coppery color in autumn.

Potted ............................................. $\$$

Ficus Repens (Climbing Fig) Extremely handsome evergreen climber. Leaves are small, dark green and heart-shaped. Clings to walls without support the same as the well-known Boston Ivy.

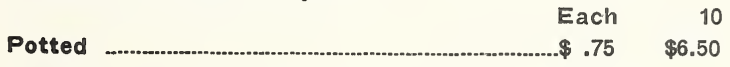

Honeysuckle One of the strongest and most widely known of the trailing plants. The foliage is of a dark green color, very glossy, and remains so throughout the entire season. The flowers are small but very fragrant, and abundant, and present a very attractive appearance.

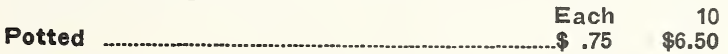

Wistaria Is one of the most desirable and highly appreciated of climbing vines. It is a very rapid, strong grower, and is particularly valued for the covering of pergolas, porches, etc. In the spring of the year it is seen heavily laden with beautiful, peashaped flowers hanging in long bunches, which are particularly noticeable on account of the absence of foliage at the blooming period.

In beauty as well as fragrance it easily surpasses any other of the climbing vines. We can furnish this beautiful climber in purple varieties.

Potted $\$ 1.00$ Each

\section{PALMS}

Phoenix Canariensis (Canary Island Date) The handsomest species of the date palm family and hardiest seing a rapid grower, it soon develops into beautiful specimens, with pinnate, dark green leaves, from 6 to 21 feet long, the divisions linear, lance-shaped, very much
pointed.

Balled, 2 to $3 \mathrm{ft}$.

Balled, 4 to $5 \mathrm{ft}$. 


\section{ROSES}

*Starred varieties are Climbers.

Price $\$ .50$ Each

AMERICA-Pearly Pink, long pointed buds.

*BILLIARD ET BARRE-Clear canary yellow; large buds. BLACK PRINCE-Dark crimson, nearly black.

*CHEROKEE-Pink.

*CL. CECILE BRUNNER-Rosy pink, salmon center.

*CL. MME. CAROLINE TESTOUT-Flowers large, bright pink. DEAN HOLE-Silvery carmine, shaded salmon.

FLORENCE FORRESTER-Snow white. Blooms very large.

*FORTUNES YELLOW-Yellow, shaded orange and rose.

GENERAL MaCARTHUR-Bright scarlet red; buds long.

GEO. DICKSON-Deep scarlet, shaded velvety crimson.

*GRUSS AN TEPLITZ-Rich scarlet.

HARRY KIRK-Creamy yellow.

HENRIETTA-Orange and coral red.

HOOSIER BEAUTY-Rich glowing crimson; buds long.

IRISH ELEGANCE-Orange to gold. Single.

LADY HILLINGDON-Apricot yellow; buds long and pointed.

LOS ANGELES-Flame pink, shaded coral and gold.

*MARECHAL NIEL-Golden yellow.

MISS C. E. VAN ROSSEM - Velvety dark red.

MME. BUTTERFLY-Brilliant pink, suffused apricot.

MRS. HENRY MORSE-Bright rose.

PAUL NEYRON-Dark rose; very large.

*PERLE D' OR-Golden yellow with orange center.

RAYON D' OR-Buds coppery orange; open flowers clear yellow. RICHMOND-Scarlet, shaded crimson.

*SILVER MOON-Creamy white.

SUNBURST-Yellow with orange center.

ULRICH BRUNNER-Geranium red, changing to carmine when open.

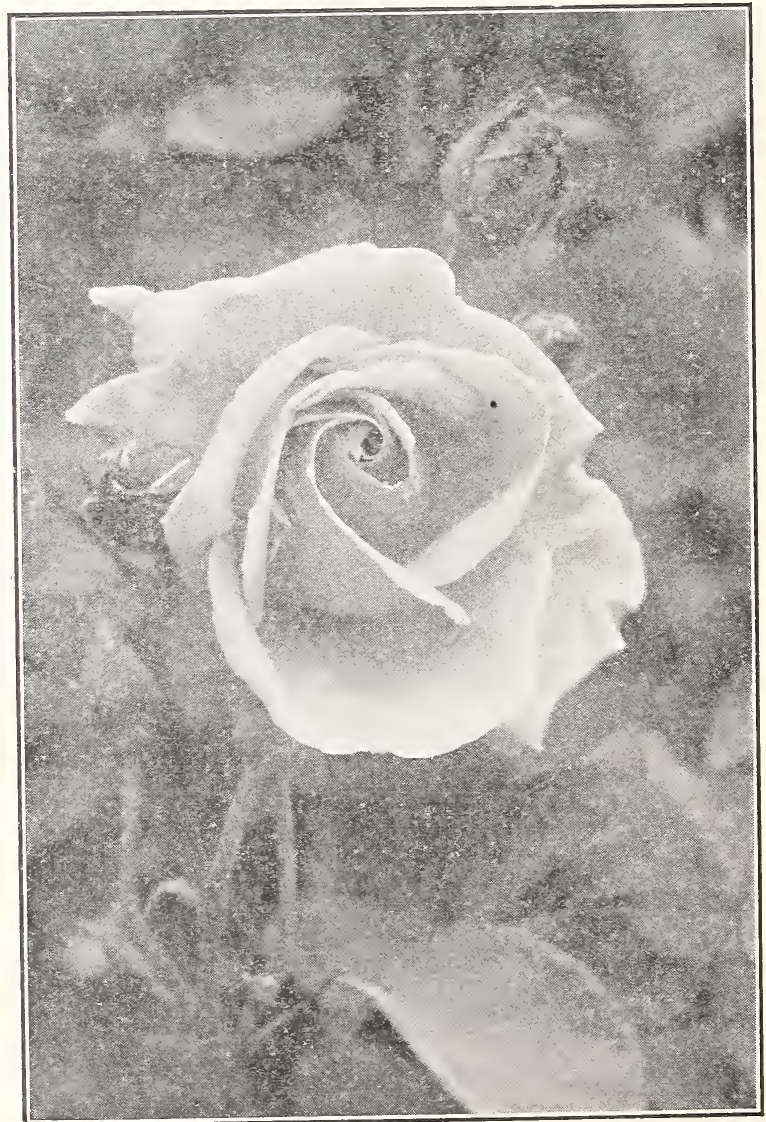




\section{The Fresno Nursery Co.}

\section{Fresno, California}

Date..

192

Amount enclosed \$.

Sold to

P. O. Address

Ship to

(Name)

Station

County of

State.

Ship via

When

If Any Item is Out of Stock, May We Substitute?

\begin{tabular}{|c|c|c|c|c|}
\hline No. & Variety & Grade & Price & $\begin{array}{c}\text { Total } \\
\text { Amount }\end{array}$ \\
\hline & & & & \\
\hline & & & & \\
\hline & & & & \\
\hline & & & & \\
\hline & & & & \\
\hline & & & & \\
\hline & & & & \\
\hline & & & & \\
\hline & & & & \\
\hline & & & & \\
\hline & & & & \\
\hline & & & & \\
\hline & & & & \\
\hline & & & & \\
\hline & & & & \\
\hline & ver) & & & \\
\hline
\end{tabular}




\section{Number of 'Trees or Plants to an Acre}

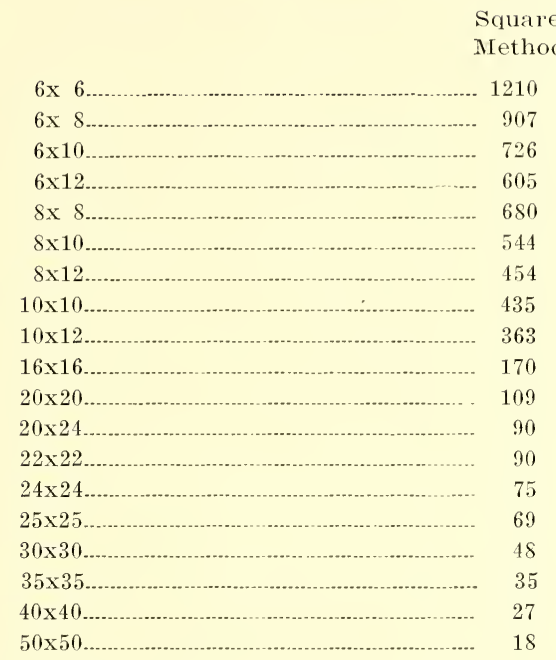

RULE-Square Method-Multiply the distance in feet between the trees by the distance the plants are apart in the rows, and the product will be the number of square feet for each plant or hill, which, divided into the number of feet in an acre $(43,560)$, will give the number of plants or trees to the acre.

RULE-Equilateral Triangle Method-Divide the number required to the acre "scilare method" by the decimal .866. The result will be the number of plants required to the acre by this method.

\section{Protect Your Trees}

We are able to supply the Fucca Protectors, in the several sizes, at the following prices:

$\begin{array}{llrrrrr}\text { Length } & \text { Width } & \begin{array}{r}\text { Weight } \\ \text { Per } 100\end{array} & \begin{array}{r}\text { Per } \\ 25\end{array} & \begin{array}{r}\text { Per } \\ 50\end{array} & \begin{array}{r}\text { Per } \\ 100\end{array} & \begin{array}{r}\text { Per } \\ 1000\end{array} \\ 30 \mathrm{in.} & 7 \mathrm{in.} & 22 \mathrm{lb} . & \$ 1.00 & \$ 1.50 & \$ 2.50 & \$ 22.00 \\ 24 \mathrm{in.} & 7 \mathrm{in.} & 18 \mathrm{lb} . & .90 & 1.25 & 2.00 & 19.00 \\ 18 \mathrm{in} . & 7 \mathrm{in.} & 13 \mathrm{lb} . & .80 & 1.10 & 1.75 & 16.00 \\ 16 \mathrm{in.} & 7 \mathrm{in.} & 12 \mathrm{lb} . & .70 & 1.00 & 1.50 & 14.50 \\ 14 \mathrm{in.} & 7 \mathrm{in.} & 10 \mathrm{lb} . & .60 & .85 & 1.40 & 13.00 \\ 12 \mathrm{in.} & 7 \mathrm{in.} & 9 \mathrm{lb} . & .50 & .75 & 1.30 & 12.00\end{array}$

\section{The Fresno Nursery Co. Inc.}

P. O. Box 615

Fresno, California 


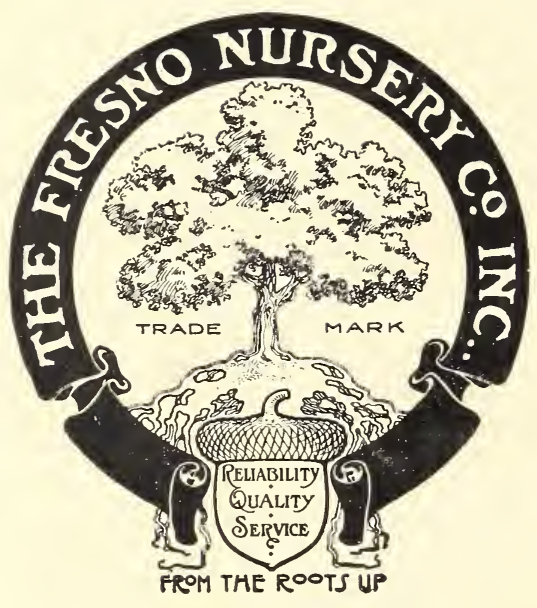

